\title{
Listericidal activity of human neutrophil cathepsin G
}

\author{
Charlotte E. Alford, Elizabeth Amaral and Priscilla A. Campbell* \\ Department of Medicine, National Jewish Center for Immunology and Respiratory Medicine, 1400 Jackson Street, \\ Denver, Colorado 80206, USA
}

(Received 2 October 1989; revised 23 February 1990; accepted 1 March 1990)

\begin{abstract}
We demonstrate that cathepsin $G$, derived from human neutrophils, exhibits potent in vitro antimicrobial activity against Listeria monocytogenes. Cathepsin G listericidal activity was by a non-enzymic mechanism and was dependent on the cationic nature of the molecule. The listericidal activity of cathepsin $G$ occurred in a manner that was both time-dependent and concentration-dependent.
\end{abstract}

\section{Introduction}

Despite the widespread acceptance of the concept that phagocytic cells are potent killers of facultative intracellular bacteria, it still remains unknown how macrophages and neutrophils kill these organisms. Many mechanisms have been proposed to explain how such bacteria are killed. Predominant among these are oxygen-dependent antimicrobial systems in which oxygen reduction is accompanied by formation of highly reactive intermediates, including superoxide anion, hydrogen peroxide and hydroxyl radical (Klebanoff, 1988). However, considerable evidence suggests that products of oxygen metabolism may not be the major effector molecules against the facultative intracellular bacterium, Listeria monocytogenes. For instance, only minimal amounts of superoxide and hydrogen peroxide were liberated when listeria antigen-elicited macrophages from immune mice were stimulated with opsonized listeria, even though these macrophages can kill listeria (Godfrey \& Wilder, 1984). Moreover, when these macrophages were incubated with scavengers of superoxide, hydrogen peroxide, hydroxyl radical or singlet oxygen, only the hydrogen peroxide scavenger catalase decreased listericidal activity, and this decrease may not have been physiologically significant (Godfrey \& Wilder, 1984). In other studies, virulence of listeria did not correlate with levels of superoxide dismutase, an enzyme which neutralizes the bactericidal effects of superoxide (Welch et al., 1979). Finally, patients with chronic granulomatous disease of childhood, who show significant deficiency in oxygen-dependent microbicidal mechanisms, nevertheless are not deficient in their ability to kill L. monocytogenes or other facultative intracellular bacteria, providing strong evidence that non-oxidative mechanisms might be very important against these microbes (Gallin et al., 1983; Donowitz \& Mandell, 1983).

In addition to oxygen-dependent systems, phagocytes are equipped with oxygen-independent means of killing micro-organisms. These include bactericidal/permeability-increasing protein, defensins, lactoferrin, lysozyme, major basic protein of eosinophils, eosinophil cationic protein and cathepsin $G$ (Elsbach \& Weiss, 1988). Of the proteins with well-established oxygen-independent antimicrobial activity, only defensins have been shown to exhibit activity against $L$. monocytogenes (PattersonDelafield et al., 1980). The purpose of the experiments described here was to test whether the cationic protein cathepsin $\mathrm{G}$ can kill L. monocytogenes. Cathepsin $\mathrm{G}$ is a chymotrypsin-like neutral protease present in the primary granules of human neutrophils (Elsbach \& Weiss, 1988). It has been detected in low quantities in human peripheral blood monocytes, but may be present in higher quantities in stimulated macrophages, such as those that express listericidal activity. Precedent for this is set by defensins, which have been found in 100-fold higher amounts in microbicidal rabbit alveolar macrophages than in non-microbicidal rabbit peritoneal macrophages (Patterson-Delafield et al., 1980). Since neutrophils kill listeria at least as well as do macrophages, and since both cells are recruited by immunologically specific $T$ cells (Czuprynski et al., 1984; 1985), cathepsin $\mathrm{G}$ can be considered as a candidate bactericidal ligand for both these professional phagocytes. Here we present experiments which show that the neutral protease cathepsin $\mathrm{G}$ exhibits potent listericidal activity. 


\section{Methods}

Cathepsin G. Purified human neutrophil cathepsin $G$ was purchased from Athens Research and Technology as a salt-free lyophilized solid. The cathepsin $\mathrm{G}$ was isolated from azurophilic granules and purified on a Sepharose-trasylol affinity column as described by Travis et al. (1978). Purity of the cathepsin $\mathrm{G}$ preparation was reported to be greater than $98 \%$ by SDS-PAGE. The activity was $2-4$ units (mg protein) ${ }^{-1}$. One unit of activity was defined as the amount of enzyme that hydrolyses one $\mu \mathrm{mol}$ succinyl-Ala-Ala-Pro-Phe-p-nitroanilide per min at $25^{\circ} \mathrm{C}$ in $100 \mathrm{~mm}$-Tris/ $\mathrm{HCl}, \mathrm{pH} 7.5$. The protein was reconstituted (according to the manufacturer's instructions) in a $50 \mathrm{~mm}$-sodium acetate $/ 0.15 \mathrm{M}-\mathrm{NaCl}$ buffer, $\mathrm{pH} 5 \cdot 5$, and used at concentrations ranging from $30-300 \mu \mathrm{g} \mathrm{ml}^{-1}$. When mixed with the bacteria, which were suspended in balanced salt solution (BSS, Mishell \& Dutton, $1967) / 5 \%$ bovine serum albumin (BSA), $\mathrm{pH} 8.5$, the final $\mathrm{NaCl}$ concentration was $0.15 \mathrm{M}$ and the final $\mathrm{pH}$ was $7 \cdot 1$. It should be noted that two different lots of cathepsin $G$ were used, one for the experiments presented in Table 1 and Fig. 1, and a different one for the experiments in Fig. 2.

Activity of heat-inactivated cathepsin $\mathrm{G}$ was determined using the method of Barrett (1981) at $37^{\circ} \mathrm{C}$. Briefly, $100 \mu \mathrm{g}$ cathepsin $\mathrm{G}$ was added to a HEPES-buffered solution containing a final concentration of 0.1 m succinyl-Ala-Ala-Pro-Phe-p-nitroanilide (Sigma). The mixture was allowed to incubate at $37^{\circ} \mathrm{C}$ for $1 \mathrm{~h}$, then the reaction was terminated with a $200 \mu \mathrm{g} \mathrm{m} \mathrm{m}^{-1}$ soybean trypsin inhibitor solution (Sigma). The absorbance of the solution was measured at $410 \mathrm{~nm}$ and the amount of nitroaniline determined from a standard curve.

Micro-organisms. Listeria monocytogenes strain EGD was maintained by periodic passage through mice. To do this, $10^{3}$ listeria $\left(0 \cdot 05 \mathbf{L D}_{50}\right)$ were injected intravenously into $(\mathrm{C} 57 \mathrm{Bl} / 6 \times \mathrm{DBA} / 2) \mathrm{F}_{1}$ mice. After $3 \mathrm{~d}$, spleens were harvested, homogenized and plated on tryptose phosphate broth (TPB; Difco). A single colony was collected and the $\mathrm{LD}_{50}$ determined. Virulence of this organism has not changed in 15 years. Bacteria were grown to exponential phase in TPB, divided into portions and stored at $-20^{\circ} \mathrm{C}$. A clinical isolate of Staphylococcus aureus was cultured in TPB, divided into portions and stored at $-20^{\circ} \mathrm{C}$. For each experiment, organisms were grown overnight in TPB, recovered and diluted as needed.

Bactericidal assays. Bacteria $\left(2 \times 10^{6}\right)$ and cathepsin G $(30-300 \mu \mathrm{g}$ $\mathrm{ml}^{-1}$ ) were mixed in a total volume of $100 \mu \mathrm{l}$ BSS containing $5 \%$ BSA and $1 \%$ HEPES in a 96-well microtitre plates (Flow Laboratories). The sodium concentration in the final incubation was $0.15 \mathrm{M}$ and the $\mathrm{pH}$ was $7 \cdot 1$. Plates were incubated at $37^{\circ} \mathrm{C}$ for $0 \cdot 5-3 \mathrm{~h}$. At the beginning of the incubation, the contents of the control well $(100 \mu \mathrm{l})$ were removed, diluted in serial tenfold dilutions in sterile distilled water, and $100 \mu \mathrm{l}$ was plated on tryptic soy agar plates (Remel). After incubation of the microtitre plate for an additional $0.5-3 \mathrm{~h}, 100 \mu 1$ samples were removed and diluted as above, and plated. After $24 \mathrm{~h}$, the number of bacterial colonies was determined.

\section{Results and Discussion}

In the first series of experiments, the time-course of killing of $L$. monocytogenes and $S$. aureus by $100 \mu \mathrm{g}$ cathepsin $\mathrm{G} \mathrm{ml}^{-1}$ was examined (Fig. 1). Killing was approximately equal for both organisms during the first $30 \mathrm{~min}$ of incubation $(54.3 \%$ killing for $S$. aureus versus $48.7 \%$ for $L$. monocytogenes). For $S$. aureus the antibacterial effect of cathepsin $G$ peaked at $30 \mathrm{~min}$ and diminished with continued incubation time until at $3 \mathrm{~h}$

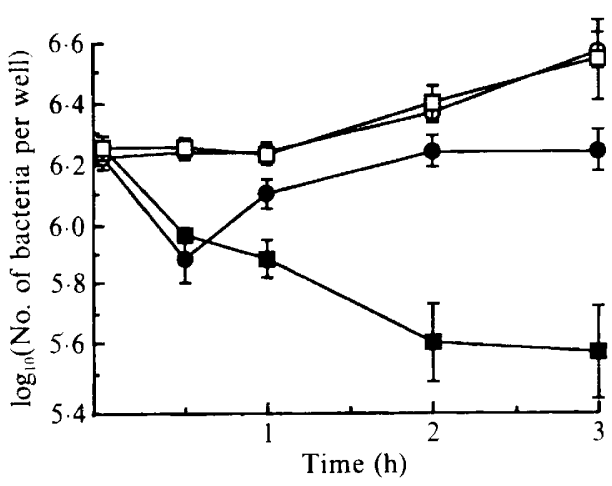

Fig. 1. Kinetics of cathepsin G-mediated killing of L. monocytogenes $(\square, \square)$ and $S$. aureus $(O, \bullet)$. Bacteria were incubated alone (open symbols) or with $100 \mu \mathrm{g}$ cathepsin $\mathrm{G} \mathrm{ml}^{-1}$ (filled symbols). Samples were taken at the indicated times. Each data point represents the mean \pm standard error from three separate experiments.

the cathepsin $G$ appeared to be bacteriostatic. This is similar to the killing seen by Odeberg \& Olsson (1975), when their dilutions are taken into consideration. In contrast, cathepsin $\mathrm{G}$ continued to exhibit extensive listericidal activity during the entire $3 \mathrm{~h}$ incubation period, with $79 \%$ killing at $3 \mathrm{~h}$. The apparent escape of $S$. aureus from the microbicidal effect of cathepsin $\mathrm{G}$ was not due to a faster growth of this organism, as the growth rate of untreated $S$. aureus was similar to that of $L$. monocytogenes for the entire $3 \mathrm{~h}$ incubation period.

In the second series of experiments, shown in Fig. 2, the concentration dependence of cathepsin $\mathrm{G}$ microbicidal activity was compared for $S$. aureus and $L$. monocytogenes. Although cathepsin $\mathrm{G}$ exhibited an antibacterial effect against both bacteria, $L$. monocytogenes was more sensitive than was $S$. aureus. In four out of four separate experiments, both $S$. aureus and $L$. monocytogenes exhibited attenuated responses to cathep$\sin \mathrm{G}$ when its concentration exceeded $100 \mu \mathrm{g} \mathrm{ml}^{-1}$.

Two sets of experiments indicate that the bactericidal effect of cathepsin $G$ was probably not due to its enzymic activity. First, bacteria were killed when the protein was heat-inactivated at $70^{\circ} \mathrm{C}$ for $1 \mathrm{~h}$ (Table 1 ), in spite of the fact that heating reduced the enzymic activity of the cathepsin $\mathrm{G}$ from 4 units $\mathrm{mg}^{-1}$ to less than 0.2 units $\mathrm{mg}^{-1}$. Second, the ability of heparin to inhibit the bactericidal activity of cathepsin $G$ also suggests that this activity is not enzymic in nature. Clark \& Higginbotham (1970) reported that the polyanion heparin, at concentrations of 38-128 U ml-1, inhibits the ability of neutrophil lysosomal cationic proteins to kill Escherichia coli. Consistent with their finding, data in Table 1 also show that the bactericidal activity of cathepsin $G$ was inhibited by $100 \mathrm{U}^{2}$ heparin $\mathrm{ml}^{-1}$ (Elkins-Sinn).

Recently Gabay et al. (1989) have reported the existence of a $29 \mathrm{kDa}$ polypeptide isolated from neutro- 


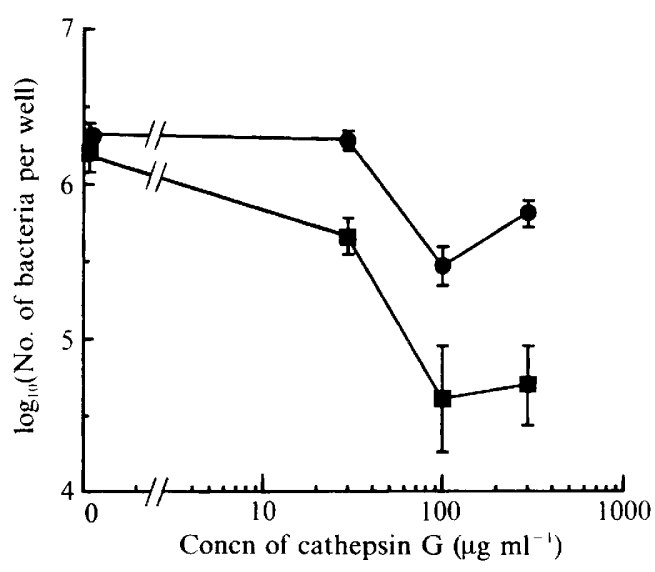

Fig. 2. Antimicrobial effect of different concentrations of cathepsin $\mathrm{G}$ on L. monocytogenes $(\boldsymbol{\square})$ and $S$. aureus $(\bullet)$. Bacteria were incubated with varying concentrations of cathepsin G. Surviving bacteria were detected by colonies counted after a $30 \mathrm{~min}$ incubation period. Each data point represents the mean \pm standard error from four separate experiments.

Table 1. Effect of heat inactivation or heparin treatment on killing of $S$. aureus and L. monocytogenes by cathepsin $G$

Bacteria were cultured alone, or with $100 \mu \mathrm{g}$ cathepsin $\mathrm{G} \mathrm{ml} \mathrm{m}^{-1}$ which was $\left({ }^{*}\right)$ or was not heated for $1 \mathrm{~h}$ at $70^{\circ} \mathrm{C}$, or with cathepsin $\mathrm{G}+100 \mathrm{U}$ heparin $\mathrm{ml}^{-1}$. Bacterial colonies were determined by plating after $30 \mathrm{~min}$ incubation. Data are presented from two separate experiments.

\begin{tabular}{|c|c|c|}
\hline \multirow[b]{2}{*}{ Treatment } & \multicolumn{2}{|c|}{$\begin{array}{c}\log _{10} \text { (No of } \\
\text { bacteria) }\end{array}$} \\
\hline & Expt 1 & Expt 2 \\
\hline S. aureus & $6 \cdot 26$ & $6 \cdot 31$ \\
\hline S. aureus + cathepsin G & 5.88 & 5.98 \\
\hline S. aureus + cathepsin $\mathrm{G}^{*}$ & 5.90 & 6.00 \\
\hline S. aureus + heparin + cathepsin G & $6 \cdot 32$ & $6 \cdot 32$ \\
\hline L. monocytogenes & $6 \cdot 28$ & $6 \cdot 38$ \\
\hline L. monocytogenes + cathepsin $\mathrm{G}$ & $5 \cdot 78$ & $5 \cdot 84$ \\
\hline L. monocytogenes + cathepsin $\mathrm{G}^{*}$ & $5 \cdot 80$ & 5.90 \\
\hline L. monocytogenes + heparin + cathepsin G & $6 \cdot 25$ & 6.35 \\
\hline
\end{tabular}

phil azurophilic granules. This polypeptide, which they named azurocidin, was as abundant as cathepsin $G$ and exhibited bactericidal activity against $E$. coli. In order to investigate the possibility that the listericidal activity seen in the experiments conducted here was due to azurocidin and not cathepsin $\mathrm{G}$, the $\mathrm{N}$-terminal sequence of the cathepsin $\mathrm{G}$ preparation was determined. Based on this analysis the cathepsin $G$ preparation was more than $99 \%$ pure with no evidence of any contamination from azurocidin.

A number of Gram-positive as well as Gram-negative bacteria have been shown to be killed by cathepsin $G$ (Odeberg \& Olsson, 1981; Shafer et al., 1986; Thorne et al., 1976). However, its ability to kill facultative intracellular micro-organisms has not previously been reported. We examined the effect of cathepsin $G$ on the facultative intracellular bacterium $L$. monocytogenes, a Gram-positive rod. Listeria was even more sensitive than the Gram-positive bacterium $S$. aureus to killing by cathepsin G. This killing appears to be independent of enzymic activity, as heat inactivation of cathepsin $\mathrm{G}$ did not destroy the listericidal activity. This is consistent with the findings of Odeberg \& Olsson (1975) and Shafer et al. (1986). Rather, our observation that listericidal activity was decreased in the presence of the anionic compound heparin suggests that microbicidal activity depends on the cationic properties of cathepsin G. This mechanism of action has been proposed by Odeberg \& Olsson (1975) and could possibly explain the finding that listericidal activity was decreased in the presence of high concentrations of cathepsin G. It is possible that when concentrations of cathepsin $\mathrm{G}$ exceed $100 \mu \mathrm{g} \mathrm{ml}^{-1}$ the positively charged cathepsin $G$ particles repel each other, decreasing slightly the effective concentration of cathepsin $\mathrm{G}$ at the bacterial cell surface.

The data presented here suggest that the small amounts of cathepsin $\mathrm{G}$ which are present in neutrophils (Senior \& Campbell, 1984) may play an important role in the killing of facultative intracellular bacteria. This finding also raises the possibility that cathepsin G may be an important molecule for macrophage listericidal activity. Although investigators have found no appreciable amounts of cationic antimicrobial proteins in either rabbit peritoneal macrophages (Hirsch, 1960) or human peripheral blood monocytes (Senior \& Campbell, 1984), this does not preclude the existence of these proteins in other macrophage populations or in other species. For example, Patterson-Delafield et al. (1980) noted a 100fold increase in the presence of the cationic proteins known as defensins in rabbit alveolar macrophages versus resident macrophages. This is of interest since in the mouse, resident macrophages generally do not exhibit listericidal activity, whereas macrophages elicited with proteose peptone do kill listeria (Czuprynski et $a l ., 1984)$. In addition, human alveolar macrophages have been reported to express high levels of listericidal activity (King et al., 1988). Thus, before considering cathepsin $\mathrm{G}$ as a macrophage listericidal protein, it will be necessary to establish whether or not this protein is present in listericidal macrophages.

\footnotetext{
The authors thank Joel Boymel and John Freed for their helpful suggestions and for performing the $\mathrm{N}$-terminal sequence analysis of the cathepsin G. This work was supported by research grant AI-11240 from the National Institute of Allergy and Infectious Diseases and by SCOR grant HL-27353 from the National Heart, Lung and Blood Institute.
} 


\section{References}

BarretT, A. J. (1981). Cathepsin G. Methods in Enzymology 80, 561565.

ClaRK, J. M. \& Higginbotham, R. D. (1970). Reversibility of heparin inhibition of the antibacterial activity of polymorphonuclear leukocyte lysosomal proteins. Infection and Immunity 1, 607-608.

Czupr ynski, C. J., Henson, P. M. \& Campbell, P. A. (1984). Killing of Listeria monocytogenes by inflammatory neutrophils and mononuclear phagocytes from immune and nonimmune mice. Journal of Leukocyte Biology 35, 193-208.

Czuprynski, C. J., Henson, P. M. \& Campbell, P. A. (1985). Enhanced accumulation of inflammatory neutrophils and macrophages mediated by transfer of $\mathrm{T}$ cells from mice immunized with Listeria monocytogenes. Journal of Immunology 134, 3449-3454.

Donowitz, G. R. \& MANDELL, G. L. (1983). Clinical presentation and unusual infections in chronic granulomatous disease. In Advances in Defense Mechanisms, vol. 3, pp. 55-75. Edited by A. J. Fauci. New York: Raven Press.

ELSBACH, P. \& WeISs, J. (1988). Phagocytic cells: oxygen-independent antimicrobial systems. In Inflammation: Basic Principles and Clinical Correlates, pp. 445-470. Edited by J. I. Gallin, I. M. Goldstein \& R. Snyderman. New York: Raven Press.

Gabay, J. E., Scott, R. W., Campanelli, D., Griffith, J., Wilde, C., Marra, M. N., Segger, M. \& Nathan, C. F. (1989). Antibiotic proteins of human polymorphonuclear leukocytes. Proceedings of the National Academy of Sciences of the United States of America 86, 5610-5614.

Gallin, J. I., Bescher, E. S., Seligmann, B. E., Nath, J., Gaither, T. \& KATE, P. (1983). NIH Conference. Recent advances in chronic granulomatous disease. Annals of Internal Medicine 99, 657-674.

GODFREY, R. W. \& WILDER, M. S. (1984). Relationships between oxidative metabolism, macrophage activation, and antilisterial activity. Journal of Leukocyte Biology 36, 533-543.
HIRSCH, J. G. (1980). Further studies on preparation and properties of phagocytin. Journal of Experimental Medicine 111, 323-337.

KING, T. E., SAVICI, D. \& CAMPBell, P. A. (1988). Phagocytosis and killing of Listeria monocytogenes by alveolar macrophages: smokers versus nonsmokers. Journal of Infectious Diseases 158, 1309-1316.

KlebanofF, S. J. (1988). Phagocytic cells: products of oxygen metabolism. In Inflammation: Basic Principles and Clinical Correlates, pp. 391-444. Edited by J. I. Gallin, I. M Goldstein \& R. Snyderman. New York: Raven Press.

Mishell, R. I. \& Dutton, R. W. (1967). Immunization of dissociated spleen cell cultures from normal mice. Journal of Experimental Medicine 126, 423-442.

ODEBERG, H. \& Olsson, I. (1975). Antibacterial activity of cationic proteins from human granulocytes. Journal of Clinical Investigation 56, 1118-1124.

Patterson-Delafield, J., Martinez, R. J. \& Lehrer, R. I. (1980). Microbicidal cationic proteins in rabbit alveolar macrophages: a potential host defense mechanism. Infection and Immunity 30, 180 192.

Senior, R. M. \& Campbell, E. J. (1984). Cathepsin G in human mononuclear phagocytes: comparisons between monocytes and U937 monocyte-like cells. Journal of Immunology 132, 2547-2551.

Shafer, W. M., ONUnKa, V. C. \& Martin, L. E. (1986). Antigonococcal activity of human neutrophil cathepsin G. Infection and Immunity 54, 184-188.

ThORNe, K. J. I., Oliver, R. C. \& BarReTT, A. J. (1976). Lysis and killing of bacteria by lysosomal proteinases. Infection and Immunity 14, 555-563.

Travis, J., Bowen, J. \& BaUgh, R. (1978). Human $\alpha$-1-antichymotrypsin: interaction with chymotrypsin-like proteinases. Biochemistry 17, 5651-5656.

Welch, D. F., Sword, C. P., Brehn, S. \& Dusanic, D. (1979). Relationship between superoxide dismutase and pathogenic mechanisms of Listeria monocytogenes. Infection and Immunity 23, 863872. 